\title{
Ensino Superior: Quem Pode Deve Pagar
}

JARBAS G. PASSARINHO

Ministro da Educação e Cultura

"Desejaríamos que pudessem ser instruidos plenamente, atingindo assim a completa humanidade, nẩo sòmente um homem, alguns homens ou muitos homens, mas todos os homens em conjunto e cada um isoladamente, jovens e velhos, ricos e pobres, nobres e camponeses, homens e mulheres, isto é, cada ser humano; para que, por fim, todo o gênero seja instruído, qualquer que seja sua idade, seu estado, seu sexo, sua nacionalidade." (Comênio)

Estas nobres palavras de Jan Amos Comênio, o grande educador falecido há precisamente três séculos, ganharam autorizada atualidade quando a UNESCO as reproduziu, em 1968 , em seu importante repositório "O Direito de Ser um Homem"; e permanecem plenamente válidas neste Ano Internacional da Educação, quando o Ministério da Educação e Cultura ultima um plano para a reformulação do custeio do ensino público superior, indispensável à concretização de um velho ideal ainda inatingido.

\section{A UTOPIA DO ENSINO GRATUITO}

O problema do custeio do ensino público reclama solução adequada, uma vez que, com cêrca de cinco por cento de nosso produto interno bruto já empregados em educação, o que nos assegura posição vanguardeira no confronto com os demais países, seria difícil cogitar de qualquer acréscimo dos recursos para êsse serviço, cada vez mais essencial.

A questão é mais ampla do que se pode imaginar, a bem dizer começando no dispositivo constitucional que estabelece a obrigatoriedade e a gratuidade universal do ensino primário,

* O artigo fol escrito em novembro de 1970. 
quando sabemos que em boa parte de nosso território êsse ensino não é obrigatório nem gratuito, pela simples razão de que não existe; e se refletirmos a respeito sem os condicionamentos decorrentes do longo convívio com a utopia da gratuidade do ensino, acabaremos percebendo que êle não existe exatamente por pretender ser gratuito.

A gratuidade universal apenas tem sentido quando é de fato universal, e não poderemos ter ensino para todos enquanto não aceitarmos essa óbvia verdade. O ensino gratuito só é uma realidade na região ou Estado que tem condições para estendêlo à população inteira, o que no Brasil provàvelmente só ocorre na Guanabara e na capital de São Paulo. Fora daí, no outro Brasil (que poderíamos subdividir em vários Brasis, do pré-histórico, que a Rodovia Transamazônica vai integrar, ao do século XXI, de Brasília), o chamado ensino gratuito não passa de antidemocrático privilégio.

A incongruência é mais evidente no ensino superior, que começa a estender-se à pós-graduação; e por isso ninguém discute de boa-fé a necessidade de reformular seu custeio, para evitar que a gratuidade indiscriminada, beneficiando também quem dela não necessita, longe de concorrer para a difusão do ensino, continue a dificultá-la.

PIOR QUE UTOPIA: INSINCERIDADE

Não falta quem, considerando êsse efeito contraproducente da gratuidade do ensino, a encare como insincera forma de resistência ao progresso social, de que se lança mão para que, sem a democrática generalização das mesmas oportunidades, se perpetue $o$ antidemocrático privilégio da escolha para poucos.

Sabe-se que a própria vida tem mecanismos niveladores, que atenuam extremos e corrigem desequilíbrios, sendo bem conhecida, por exemplo, a teoria ou pelo menos a crença da alternada ascensão e queda das famílias, em ciclos médios de três gerações; o fenômeno, em geral apontado no terreno econômico, também parece ocorrer na área intelectual, onde, parafraseando a trilogia do pai rico, filho nobre, neto pobre, têm sido assinalados casos de pai sábio, filho pedante, neto ignorante.

Todavia, não podemos deixar ao lento azar dos meios naturais a correção de injustiças e o aperfeiçoamento da sociedade, para não falar no equilíbrio social; temos de corrigir os erros e combater os privilégios, para que cheguem a todos as vantagens da ciência, da cultura, do progresso. Assegurar a igual- 
dade de oportunidades é, sem dúvida, a mais nobre atribuição do Poder Público, com a educação ao alcance de todos constituindo o instrumento mais poderoso para seu desempenho.

Se a evolução individual se completou pelo menos teòricamente com o desaparecimento da escravidão, o grande desafio de nosso tempo é a evolução social, no sentido de menor diferença entre pobres e ricos, e a resposta adequada terá de começar pelo nivelamento das oportunidades de educação.

\section{SOLUÇÃO MODERADA E VIÁVEL}

Ao que tudo indica a solução poderá ser obtida mediante aproveitamento da legislação do impôsto de renda, cobrandose parte do custo do ensino, nas universidades federais, quando o pai do aluno (ou êle próprio) pagar êsse impôsto - sem discriminação entre quem paga e quem não paga e sem qualquer reflexo da obrigação de pagar sôbre a vida escolar do estudante, que de maneira alguma será afetada, nem mesmo na hipótese de sonegação ou impontualidade.

A proposição em estudo tem o mérito inicial de estabelecer um critério objetivo e justo para distinguir entre quem deve e quem não deve participar do custeio do ensino, e esta, em verdade, era a questão básica, para a qual enfim se encontrou resposta na conjugação com o impôsto de renda, outro extraordinário fator de ordenamento e racionalização da sociedade democrática.

O que o interêsse público exige não é a gratuidade indiscriminada e sim uma gratuidade limitada aos que dela necessitem, sendo mesmo de desejar que êsse número se torne cada vez menor, para ser cada vez maior o número de estudantes. Conhecido escritor ressaltou que o importante numa escola pública não é que ela seja gratuita, mas que seja uma escola - isto é, que exista e funcione bem.

Sem se dispor ainda de elementos para levantar o custo exato do ensino oficial, pensa-se numa solução prática: arbitrar um valor médio, que, aplicável a todos os casos, deverá conduzir sempre a uma participação inferior ao custo real dêsse serviço, hoje tão indispensável.

Em mais de um ensejo se tem tentado resolver a questão, inclusive mediante legislação específica, sem que, todavia, tenha sido possível chegar a resultados concretos. A solução agora proposta não é completa, mas dificilmente poderia ser, e talvez nem devesse, pois o melhor caminho é quase sempre gradual, 
paulatino; com o tempo se poderá ir mais longe, porém o essencial é começar, dar o primeiro passo - ou o pontapé inicial, para usar uma linguagem que o Brasil inteiro fala.

\section{OUTRAS MEDIDAS}

Para proporcionar ensino a todos, assegurando igualdade de oportunidades, não bastará a reformulação do custeio do ensino superior, porém o Ministério da Educação, cônscio das responsabilidades que lhe cabem no govêrno patriótico do Presidente Médici, já está lutando em outros setores, como o MOBRAL, em plena atuação de âmbito nacional; o ensino fundamental, em final de estudos; os ginásios orientados para o trabalho, em adiantada fase de implantação; a reforma universitária, também em boa marcha; o desenvolvimento do ensino de pós-graduação, indispensável a essa reforma, através do preparo e aperfeiçoamento do corpo docente de ensino superior; e assim por diante.

A cobrança parcial do ensino universitário não será tudo, mas sem isso todo esfôrço será pouco, para não dizer inútil.

\section{NINGUÉM DESEJA PRIVILÉGIOS}

Os próprios estudantes e suas famílias decerto acolherão com simpatia uma modalidade moderada de participação no custeio do ensino superior: com a generosidade e lucidez da juventude, os moços sabem que o ensino gratuito só beneficia uns poucos privilegiados, e no fundo ninguém se sente à vontade nessa condição. Compreendem inclusive que haverá maior número de vagas quando a gratuidade deixar de beneficiar os que dela não necessitam. 